\title{
Mesoscale eddies and submesoscale structures of Persian Gulf Water off the Omani coast in spring 2011
}

\author{
Pierre L'Hégaret $^{1}$, Xavier Carton ${ }^{1}$, Stephanie Louazel ${ }^{2}$, and Guillaume Boutin ${ }^{1}$ \\ ${ }^{1}$ Laboratoire de Physique des Oceans/UMR6523, UBO, 6 avenue Le Gorgeu CS93837, 29238 Brest CEDEX 3, France \\ ${ }^{2}$ Service Hydrographique et Oceanographique de la Marine, 13 rue de Chatellier CS92803, \\ 29228 Brest CEDEX 2, Brest, France
}

Correspondence to: Pierre L’Hégaret (pierre.lhegaret@outlook.com)

Received: 8 October 2015 - Published in Ocean Sci. Discuss.: 13 November 2015

Revised: 9 April 2016 - Accepted: 27 April 2016 - Published: 20 May 2016

\begin{abstract}
The Persian Gulf produces high-salinity water (Persian Gulf Water, PGW hereafter), which flows into the Sea of Oman via the Strait of Hormuz. Beyond the Strait of Hormuz, the PGW cascades down the continental slope and spreads in the Sea of Oman under the influence of the energetic mesoscale eddies. The PGW outflow has different thermohaline characteristics and pathways, depending on the season. In spring 2011, the Phys-Indien experiment was carried out in the Arabian Sea and in the Sea of Oman. The Phys-Indien 2011 measurements, as well as satellite observations, are used here to characterize the circulation induced by the eddy field and its impact on the PGW pathway and evolution.

During the spring intermonsoon, an anticyclonic eddy is often observed at the mouth of the Sea of Oman. It creates a front between the eastern and western parts of the basin. This structure was observed in 2011 during the Phys-Indien experiment. Two energetic eddies were also present along the southern Omani coast in the Arabian Sea. At their peripheries, ribbons of freshwater and cold water were found due to the stirring created by the eddies.

The PGW characteristics are strongly influenced by these eddies. In the western Sea of Oman, in 2011, the PGW was fragmented into filaments and submesoscale eddies. It also recirculated locally, thus creating salty layers with different densities. In the Arabian Sea, a highly saline submesoscale lens was recorded offshore. Its characteristics are analyzed here and possible origins are proposed. The recurrence of such lenses in the Arabian Sea is also briefly examined.
\end{abstract}

\section{Introduction}

The Indian Ocean, the third tropical basin in size, is bounded to the north by the Asian landmass. This landmass leads to the existence of monsoons, which strongly influence the regional oceanic circulation. The northwestern part of the Indian Ocean is comprised of different sub-basins, each with specific geographic and climatic characteristics. This study focuses on two of them, the Sea of Oman (or Gulf of Oman) and the Arabian Sea (see Fig. 1). The Sea of Oman connects the Persian Gulf to the Arabian Sea; this sea deepens and widens along its zonal axis, from the Strait of Hormuz to its mouth, at Ra's Al Hadd. The northwestern Arabian Sea has a narrow continental shelf, which widens only from Ra's Al Hadd to Ra's Madrakah along the Omani coast (see again Fig. 1 for locations). The Arabian Sea is also crossed by the Owen Fracture Zone from northeast to southwest, with diving and rising of the seafloor along the fault.

The surface circulation around the Arabian Peninsula is forced by the atmospheric monsoon cycle. During the Southwest monsoon, in summer, strong and steady southwesterly winds run across the basin (see Findlater, 1969); they reverse in winter, during the Northeast monsoon, with also steady but weaker winds. The intermonsoons, in spring and fall, are marked by a decrease in wind intensity and a loss of preferred direction.

The upper ocean response is highly variable spatially and seasonally. In summer (winter), alongshore currents extend along a "belt", with a negative (positive) sea level anomaly along the western and northern coasts. These anomalies grow under the influence of the monsoon wind stress, associated 


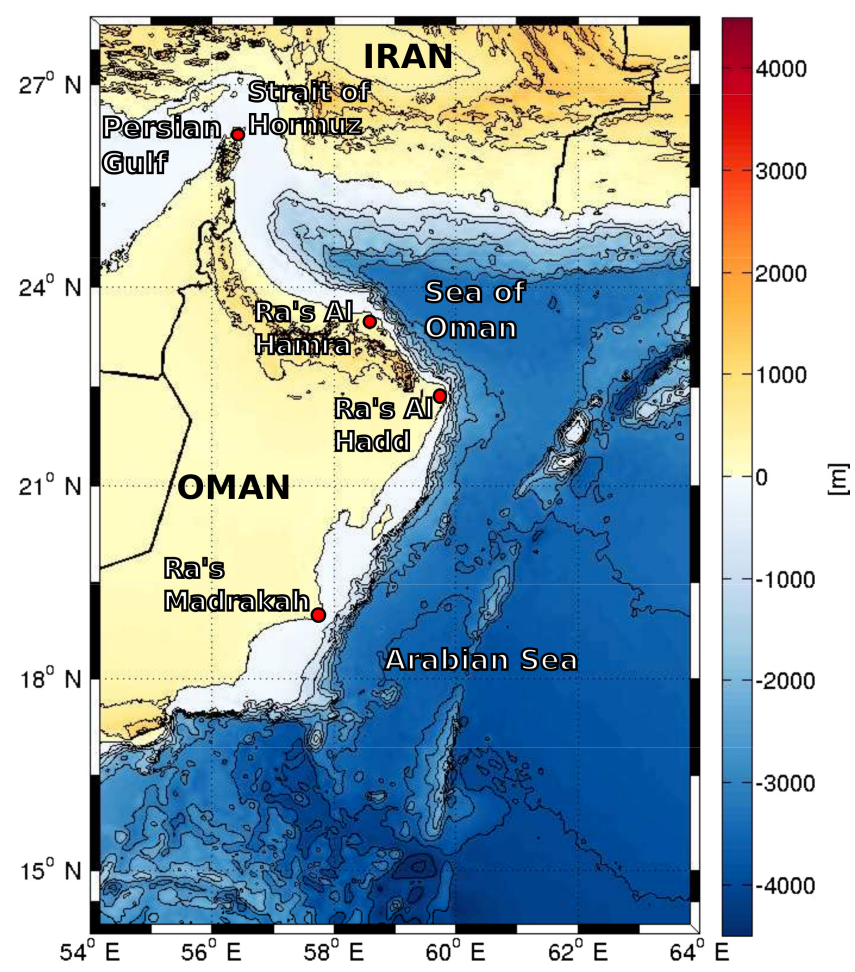

Figure 1. Topographic map of the Arabian Sea and Sea of Oman with the locations of interest.

with upwellings (downwellings) (see Lee et al., 2000). These currents then destabilize to form meanders and mesoscale eddies with a radius comparable with or slightly larger than the first baroclinic radius of deformation (about $40 \mathrm{~km}$ in the region; see Chelton et al., 1998). These eddies are known to dominate the near-surface circulation offshore (see Fischer et al., 2002) and to induce horizontal transports. They have a vertical influence on the water masses at depth (see Bower and Furey, 2012, and Carton et al., 2012). Other processes can lead to the formation of such eddies, depending on the location and the season. Al Saafani et al. (2007) identified eddies in the Gulf of Aden generated by Rossby waves emitted from the Indian coast or amplified in the interior of the basin. This mechanism is also present in the northern Arabian Sea, with Rossby waves being forced by wind and by coastal Kelvin waves (see L'Hégaret et al., 2015).

Over the Persian Gulf, steady winds and solar heating lead to intense evaporation (see Privett, 1959; Meshal and Hassan, 1986); this region also has little freshwater inflow (through precipitation and rivers; see Reynolds, 1993); the large deficit of precipitation (or river inflow) over evaporation results in the formation of highly saline water in the Persian Gulf. This water mass, called PGW (Persian Gulf Water), with salinity above $40 \mathrm{psu}$, flows into the Sea of Oman via the Strait of Hormuz. The density of the outflowing PGW varies seasonally, the densest water being formed in winter (Swift and Bower, 2003). In the Sea of Oman, the PGW outflow equi- librates around $250 \mathrm{~m}$ depth, mixing with the fresher Indian Ocean Central Water (IOCW). Another salty water mass, the Arabian Sea High Salinity Water (ASHSW), with salinity above 36.6 psu, forms in the Arabian Sea in winter (see Kumar and Prasad, 1999) and occupies the upper part of the water column.

In the past, a few dedicated cruises provided observations to describe the PGW pathway out of the Persian Gulf and its variations in the Sea of Oman. The PGW outflow was usually presented as a southeastward flow along the coast of Oman (see Premchand et al., 1986). Indeed, in October-November 1999, during the fall intermonsoon, the GOGP99 ${ }^{1}$ experiment at sea sampled the PGW outflow and identified it as a coastal flow, extending to the southern coast of Oman (see Pous et al., 2004). During other seasons, the path of the PGW in the Gulf of Oman is less regular, as shown by observations and by numerical modeling; also, PGW can exit in the form of short pulses (see Banse, 1997; Senjyu et al., 1998; Bower et al., 2000; Prasad et al., 2001; Thoppil and Hogan, 2009; Wang et al., 2012; Wang et al., 2013). Recently, ARGO floats (see Carton et al., 2012; L'Hégaret et al., 2013) and HYCOM numerical simulations (see L'Hégaret et al., 2015) confirmed that during other seasons, PGW can be expelled from the coast into the Sea of Oman. These ejections were related to the presence of mesoscale eddies in the Sea of Oman, and especially to the presence of a dipole in spring; different offshore ejection mechanisms were identified. PGW ejection was also identified in response to tropical atmospheric cyclones (in particular cyclone Gonu; Wang et al., 2012, 2013).

In spring 2011, the Phys-Indien experiment was carried out around the Arabian Peninsula, recording the thermohaline and dynamical characteristics of the upper ocean. Mesoscale surface eddies and submesoscale fragments of PGW were sampled in the Sea of Oman and off Ra's Al Hadd, in the Arabian Sea.

The objective of this paper is twofold. First, it describes the mesoscale surface eddies in spring 2011 and how they advect the surrounding water masses. Second, it presents the structure and possible recurrence of submesoscale PGW fragments, in particular those embedded in mesoscale eddies. To achieve these objectives, in situ data collected during the Phys-Indien experiment and satellite measurements are used. The altimetric data provide temporal continuity to study the evolution of the mesoscale features (but with a low spatial resolution). The in situ observations give a finer-scale, but instantaneous, description of the eddies and water masses.

\subsection{The Phys-Indien 2011 measurements}

The Phys-Indien 2011 experiment measured the circulation and water masses in the sub-basins around the Arabian Peninsula, from the Red Sea to the Persian Gulf, starting

\footnotetext{
${ }^{1}$ GOGP99 for the Gulf of Oman - Persian Gulf experiment in October 1999
} 


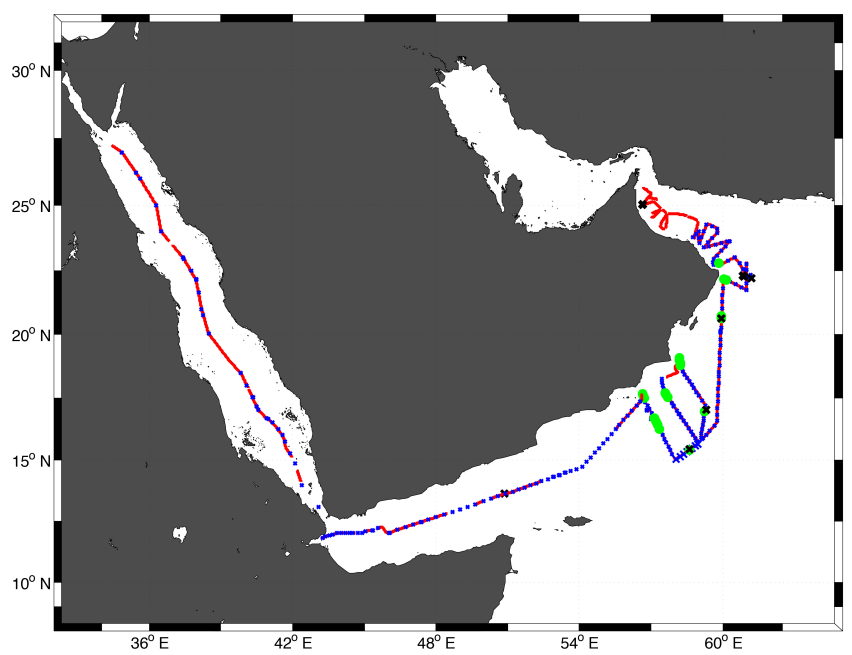

Figure 2. Location of the Phys-Indien 2011 measurements. The red line follows the VM-ADCP and SeaSoar lines (with the exception of the Red Sea and Gulf of Aden, where only the VM-ADCP was activated). The blue crosses and green circles represent the positions of XBT-XCTD casts and of CTD-LADCP stations, respectively. The black crosses represent the launch positions of floats (Surdrift and PROVOR).

in late February until April 2011; it relied on various devices: two $\mathrm{CTD}^{2}$ probes on a SeaSoar, a CTD and a lowered $\mathrm{ADCP}^{3}$ at stations, $\mathrm{XBT}$ and $\mathrm{XCTD}$ probes ${ }^{4}, \mathrm{VM}^{-} \mathrm{ADCP}^{5}$, Surdrift buoys and profiling floats, and meteorological sensors. The Phys-Indien sections are shown in Fig. 2. In particular, these sections crossed mesoscale eddies and the PGW outflow and fragments. This study focuses on the measurements in the northwestern Arabian Sea and in the Sea of Oman, in March 2011.

In the SeaSoar sections, pressure, temperature and conductivity are measured in the upper $350 \mathrm{~m}$ of the water column with accuracies of $10^{-3}{ }^{\circ} \mathrm{C}, 3 \times 10^{-4} \mathrm{~S} \mathrm{~m}^{-1}$ and $0.015 \%$ of the pressure value. Salinity is calculated from temperature and conductivity. In this region, strong horizontal and vertical thermohaline gradients occur, which can lead to biases in temperature and salinity measurements by the SeaSoar. These biases are due to thermal inertia of the sensors, and mostly occur between the lowering and rising of the device, which result in a delay between the conductivity and temperature measurements (see Barth et al., 1996). These errors are corrected by applying a couple of coefficients, a first one correcting the amplitude of the signals between the rising and the lowering of the SeaSoar, and a second coefficient correcting the time delay (see Lueck and Picklo, 1990 and Mensah et al., 2008). Once corrected, the SeaSoar measurements

\footnotetext{
${ }^{2} \mathrm{CTD}$ for conductivity, temperature, depth

${ }^{3} \mathrm{ADCP}$ for acoustic Doppler current profiler

${ }^{4} \mathrm{XBT}$ and XCTD for expendable bathythermograph and CTD

${ }^{5} \mathrm{VM}$-ADCP for vessel-mounted acoustic Doppler current profiler
}

are validated against CTD station or XCTD cast data (such stations or casts were achieved along the SeaSoar transects). The relative residual error of the corrected SeaSoar salinity remains below $0.5 \%$ at the CTD stations.

The horizontal velocity is obtained with a $38 \mathrm{kHz} \mathrm{VM}-$ ADCP; this device measures currents from the surface to about $1000 \mathrm{~m}$ depth; the depth range depends on the matter in suspension in seawater, which can reflect the acoustic signal. In a few occurrences, currents could be measured down to $1600 \mathrm{~m}$ depth. The accuracy of VM-ADCP in the horizontal components of velocity is $5 \times 10^{-3} \mathrm{~m} \mathrm{~s}^{-1}$. VM-ADCP provides high-resolution measurements but is sensitive to noise due to biological activity. Here, a low-pass filter is applied to the signal, keeping the structures with a size larger than $3 \mathrm{~km}$, to focus on the submesoscale and mesoscale processes. Another VM-ADCP, with $150 \mathrm{kHz}$ frequency, was activated, but its data are not shown here (due to overly noisy measurements and a shallow reach). These data are used nevertheless to validate the $38 \mathrm{kHz}$ ADCP measurements in the upper ocean. A few VM-ADCP sections were interrupted or were too noisy, thus leading to blanks. No interpolation is carried out and the blanks are displayed in the figures. Blanks (due to interruptions) can also appear on a few of the SeaSoar transects.

During Phys-Indien, five drogued Surdrift buoys were deployed and programmed for 180 days of recording. These surface buoys are connected to a large holey-sock drogue by a thin Kevlar cable, 80-250 m long. A test of the acceleration of each buoy is applied to determine a possible loss of the drogue. These buoys are positioned by Argos, their trajectories are sampled every hour, and a thermistor sensor gives the surface temperature at each recording.

Also, six PROVOR floats were deployed during this cruise. They are positioned via Argos when they surface at the end of each 5-day cycle. These floats are equipped with a CTD probe providing temperature, conductivity and pressure with an accuracy of $0.01{ }^{\circ} \mathrm{C}, 10^{-3} \mathrm{~S} \mathrm{~m}^{-1}$ and $1 \mathrm{dbar}$, respectively. Their parking depth was programmed to $700 \mathrm{dbar}$ (instead of the usual 1000 dbar); they dived to 2000 dbar every 5 days and acquired data while rising to the surface, where these data were transmitted.

\subsection{Thermodynamical and dynamical quantities derived from the measurements}

To describe the structure of the mesoscale eddies, surface maps of the MADT anomaly ${ }^{6}$ are computed at the period and location of Phys-Indien measurements; from this anomaly, surface geostrophic velocities $(U, V)$, relative vorticity and the Okubo-Weiss quantity are obtained through derivations. The Okubo-Weiss quantity is defined as the difference (in

\footnotetext{
${ }^{6}$ MADT stands for mean altimetric dynamic topography; the anomaly is the residual of MADT minus an instantaneous spatial average, over the domain, of MADT
} 
norm) between total deformation and relative vorticity

$$
\begin{aligned}
\mathrm{OW} & =\sigma_{\text {strain }}^{2}+\sigma_{\text {shear }}^{2}-\omega^{2} \\
\text { with the shear, } \quad \sigma_{\text {shear }} & =\frac{\partial V}{\partial x}+\frac{\partial U}{\partial y} \\
\text { the strain } \quad & \sigma_{\text {strain }}=\frac{\partial U}{\partial x}-\frac{\partial V}{\partial y}
\end{aligned}
$$$$
\text { and the relative vorticity } \omega=\frac{\partial V}{\partial x}-\frac{\partial U}{\partial y} \text {. }
$$

The Okubo-Weiss quantity is positive in regions where deformation dominates rotation, and it is negative where vorticity dominates.

From the thermohaline data, density and spice (or spiciness) are calculated along the sections. In situ density is obtained by an equation of state from IOC and IAPSO (2010). The density anomaly $\sigma_{0}$ is displayed. Using $T_{0}, S_{0}$ and $\rho_{0}$, the reference temperature, salinity and density, $20^{\circ} \mathrm{C}, 37 \mathrm{psu}$ and $998 \mathrm{~kg} \mathrm{~m}^{-3}$, spice $\gamma$ is calculated via

$\gamma=\gamma_{0}\left[1+\alpha\left(T-T_{0}\right)+\beta\left(S-S_{0}\right)\right]$

(according to the definition by Smith and Ferrari, 2009). Spice concentrations highlight here the submesoscale structures at the periphery of the eddies. This variable shows a marked difference between the salty waters trapped inside the mesoscale eddies and the fresher water patches surrounding them. Using the slope of spice layers across isopycnic layers, their formation by the eddy shear and strain can be studied.

Using velocities from the VM-ADCP measurements and density from the SeaSoar, a two-dimensional Ertel potential vorticity (EPV; see Hoskins, 1974) can be calculated along each section:

$\mathrm{EPV}=\left(f+\frac{\partial V_{g}}{\partial x}\right) \frac{\partial b}{\partial z}-\frac{\partial V_{g}}{\partial z} \frac{\partial b}{\partial x}$,

with $b=-\left(\frac{g}{\rho_{0}}\right) \rho$ the buoyancy. Its anomaly is

$\mathrm{EPVA}=\mathrm{EPV}-f \frac{\partial \bar{b}}{\partial z}$.

Note that this calculation leads to some small-scale noise in the EPV anomaly due to the SeaSoar and VM-ADCP resolution; the figures presented in the text are slightly smoothed for legibility.

\section{Onset of the spring 2011 intermonsoon mesoscale situation}

The spring intermonsoon extends on average from February to May in the Arabian Sea. During this period, the wind relaxes between the two local maxima of the winter and summer monsoons. In 2011, the wind stress curl off Ra's Al Hadd
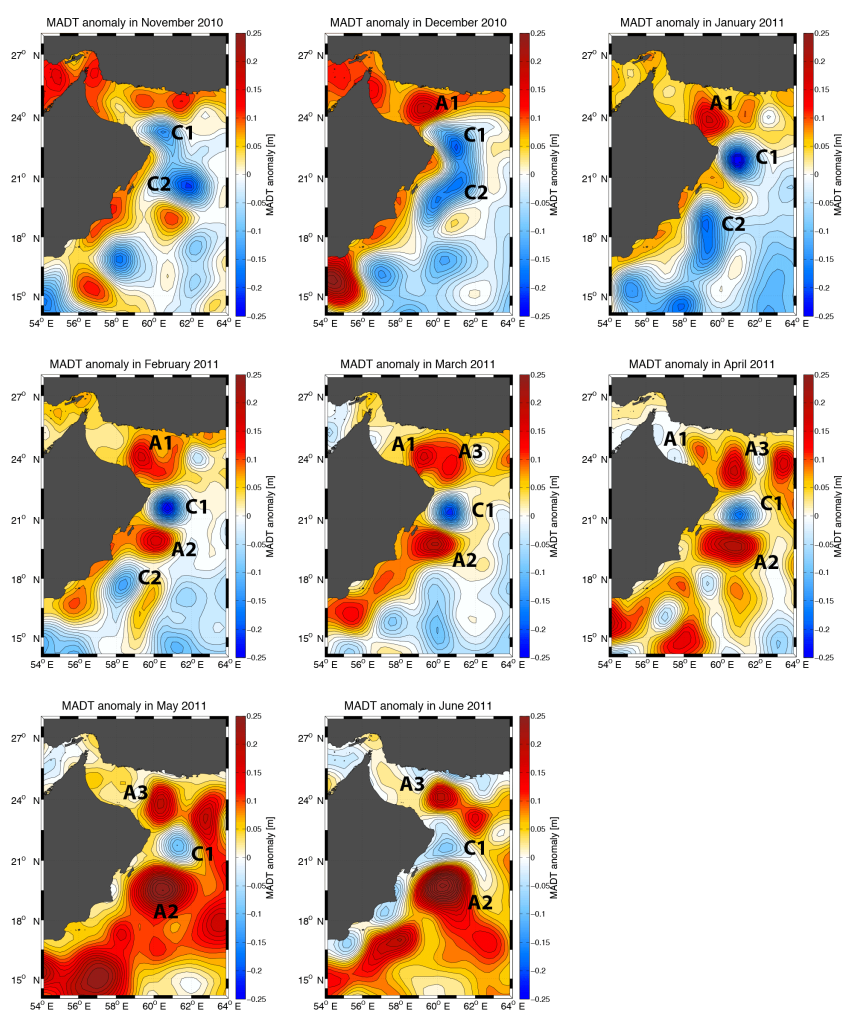

Figure 3. Maps of the MADT (altimetric) anomaly averaged over a month, from November 2010 to June 2011. Anticyclone A1 formed and remained in the eastern Sea of Oman from December 2010 to April 2011; anticyclone A2 formed from the coastal "belt" along the Omani coast in February 2011, intensifying during summer 2011; anticyclone A3 split from A1 in March 2011 and remained at the mouth of the Sea of Oman; cyclone C1 formed and remained off Ra's Al Hadd in late 2010, intensifying until February 2011; cyclone C2 formed in late 2011 and drifted southwestward.

changed sign from March to May. During this period, the wind work leads to a deepening of the surface eddies (see L'Hégaret et al., 2015 and Vic et al., 2014).

In Fig. 3, the MADT anomaly is displayed over the Sea of Oman and the northwestern Arabian Sea from the winter monsoon to the beginning of the summer monsoon (November 2010 to June 2011). In November 2010, an alongshore current, associated with a positive MADT anomaly, flowed along the southern coast of Oman (the coastal "belt" of the MADT anomaly described in L'Hégaret et al., 2015); it is driven by the Ekman currents. This current formed meanders in December 2010 and January 2011 along the coast of Oman. During these months, mesoscale cyclone C1 exited the Sea of Oman and cyclone C2 propagated southwestward along the coast of Oman. Both the Owen fracture zone and the coastal current can channel these cyclones along the coast.

From December 2010 through February 2011, the positive MADT anomaly in the Sea of Oman showed the onset of a large anticyclonic eddy - A1. This anticyclone A1 was part 
of a dipole recorded by ARGO floats, located nearly every spring near Ra's al Hamra (see L'Hégaret et al., 2013). South of Ra's Al Hadd, in the Arabian Sea, an alongshore meander formed an anticyclone (A2), splitting apart the $\mathrm{C} 1$ and $\mathrm{C} 2 \mathrm{cy}-$ clones. The first cyclone (C1) remained east of Ra's Al Hadd until April; the second cyclone (C2) drifted southwestward, decreasing in intensity.

From March 2011 through May 2011, A1 split into two anticyclones, A1 and A3. Thus during the Phys-Indien experiment three main vortices lined up along $61^{\circ} \mathrm{E}$, south and north of Ra's Al Hadd: the anticyclone at the mouth of the Sea of Oman (A3), the cyclone at Ra's al Hadd (C1) and the anticyclone south of it (A2).

In May-June 2011, with the onset of the summer monsoon, the sea surface warmed up, cyclone $\mathrm{C} 1$ weakens, A2 intensified in relation to the increasing negative wind stress curl, and the alongshore current started to form with a negative MADT anomaly in response to the onset of the summer monsoon.

The observed evolution of the structures in the region during spring 2011 corresponds on average to the usual spring intermonsoon, with large structures dominating the surface circulation and a strong anticyclonic signature in the eastern Sea of Oman. The eddies influence the distribution of the sea surface temperature, intensifying the thermal front near Ra's al Hadd (and, later on, advecting cold water offshore). The following section focuses on the dynamical structure of these eddies and on their influence on the water masses at depth, as evidenced by the Phys-Indien experiment data.

\section{Structure of mesoscale eddies and their relation to the PGW distribution}

This section focuses on the vertical characteristics of the eddies presented earlier and on their relations to the PGW outflow structure, using the Phys-Indien experiment data. In order to understand the relation between the vertical and horizontal structures, Fig. 4 displays surface fields derived from the MADT. The relative vorticity, Okubo-Weiss parameter and geostrophic velocities are calculated through derivations.

The relative vorticity field at the surface (upper right in Fig. 4) provides information on the horizontal extent and polarity of the eddies. The most intense features were A1 and C2 in the Arabian Sea, with radii of $80 \mathrm{~km}$. In the Sea of Oman, a train of eddies is found with alternating cyclones and anticyclones, with radii half the size of their Arabian Sea's counterparts, that is, about $40 \mathrm{~km}$.

The Okubo-Weiss parameter distribution at the surface shows that the structures are dominated by high concentrations of vorticity, and thus are robust when exposed to external strain or shear. $\mathrm{C} 1$ and $\mathrm{A} 2$ stand out as robust vortices in the bottom left panel (Fig. 4), as well as A1. Furthermore, this Okubo-Weiss parameter indicates the location where de-
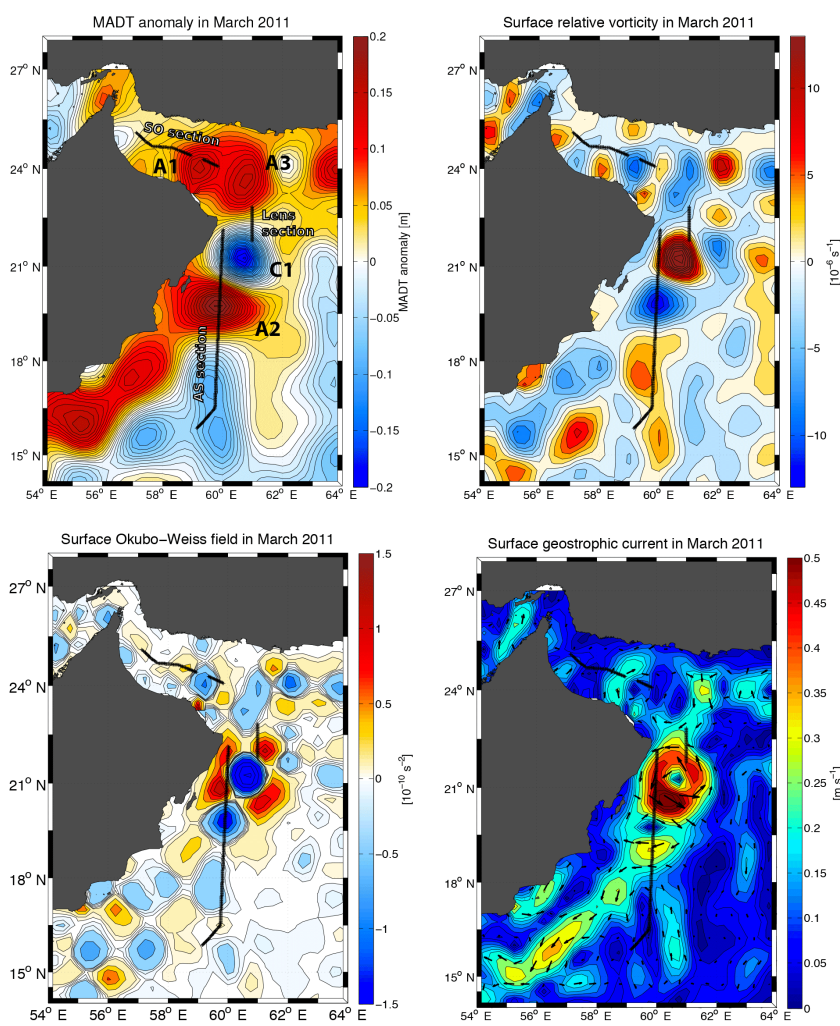

Figure 4. Maps of the surface fields averaged from 16 to 30 March 2011, during the measurements south of Ra's Al Hadd (AS section), in the lens off Ra's Al Hadd (lens section), and across the Sea of Oman (SO section). Fields are ADT anomaly (top, left), relative vorticity (top, right), Okubo-Weiss criterion (bottom, left), and geostrophic velocity (bottom, right).

formation dominates, that is, around $\mathrm{C} 1$, but also between $\mathrm{A} 1$ and the Omani coast, and north of A3 near the Iranian coast.

The bottom right panel of Fig. 4 displays the geostrophic velocity intensity and direction at the surface. The most energetic currents are observed around $\mathrm{C} 1, \mathrm{~A} 2$ and along the coastal "belt". In Bower and Furey (2012), Carton et al. (2012) and L'Hégaret et al. (2013), correlations are found between the surface circulation induced by the eddies and the structure of the salty outflows from the Red Sea and the Persian Gulf. The velocity map gives a first glimpse of the pathway of the PGW: in the western Sea of Oman, the water mass equilibrated and flowed along the southern coast; then, it was ejected northward from the coast at Ra's Al Hamra, under the influence of A1. It flowed along the Iranian coast, eastward then southward (rotating around $\mathrm{A} 1$ and $\mathrm{A} 3$ ), and finally it recirculated around $\mathrm{C} 1$ before either escaping offshore in the Arabian Sea or flowing southwestward around $\mathrm{A} 2$ and $\mathrm{C} 2$.

Superimposed on these maps, the positions of three sections of interest are indicated. The first section focuses on the Sea of Oman (SO section), the second one on the Arabian Sea (AS section), and the last one crosses a submesoscale 
lens of PGW off Ra's Al Hadd (lens section). These vertical sections present velocities measured with the VM-ADCP, the Ertel potential vorticity field, density and spice (see Sect. 2 for computation).

\subsection{Sea of Oman}

From 22 to 30 March the Phys-Indien experiment performed cross sections in the Sea of Oman. A composite section (SO section) crossing this basin zonally is presented and described here.

As observed in the surface maps (Fig. 4) of the MADT anomaly and even more in surface velocity, the SO section crossed eddies with alternate polarities. The upper panel of Fig. 5 is a VM-ADCP velocity section showing an anticyclone between 56 and $57.8^{\circ} \mathrm{E}$, a cyclone between 57.8 and $58.8^{\circ} \mathrm{E}$ and the $\mathrm{A} 1$ anticyclone from 58.8 and $60^{\circ} \mathrm{E}$, the latter not sampled across its center. The density section of Fig. 5 is coherent with the eddy dynamical signatures, showing a lowering of the isopycnals below the anticyclones and a rising below the cyclone. The EPV anomaly field, though noisy, shows the structure of the eddies in the upper 100-150 m, but also a strong signature below $150 \mathrm{~m}$ depth.

The eddies are surface intensified in temperature and salinity anomalies, down to 200-300 m depth, but their dynamical influence reaches more deeply. Tilts of the velocity field are found below the central cyclone at $58^{\circ} \mathrm{E}$ and also at $57.5^{\circ} \mathrm{E}$. These tilts are colocalized with a spreading of the isopycnals indicated by grey and green crosses in the density panel Fig. 5. The spice section (see below) will identify the structures associated with these tilts.

The spice section (bottom panel, Fig. 5) is an efficient marker of the PGW structure. The first noticeable feature at $100 \mathrm{~m}$ depth is the strong gradient of spice across $58.8^{\circ} \mathrm{E}$ (the blue line), at the western edge of anticyclone A1. West of this line, several patches of PGW are marked by high spice concentrations, with two lenses at 58 and at $57.5^{\circ} \mathrm{E}$ (green and grey lines); east of $58.8^{\circ} \mathrm{E}$, no such patch is observed. These lenses are correlated in position with negative anomalies in the EPV anomaly field. The circulation at the PGW depth from 58 to $59^{\circ} \mathrm{E}$ was northward with a recirculation around $\mathrm{A} 1$ and $\mathrm{A} 3$; this corresponds to the ejection of PGW from the Omani coast near Ra's Al Hamra. Below the surface, this section also shows filaments of IOCW (with weaker spice) wrapping around the PGW patches.

\subsection{Arabian Sea}

The Arabian Sea (AS) section studied here is located south of Ra's Al Hadd, from 16 to $22^{\circ} \mathrm{N}$ almost along $60^{\circ} \mathrm{E}$; it was carried out from 16 to 19 March 2011.

The surface fields from Fig. 4 indicate that the AS section crossed, from south to north, cyclone $\mathrm{C} 2$, the core of anticyclone $\mathrm{A} 1$ and the western edge of cyclone $\mathrm{C} 1$, thus, between 19 and $20.5^{\circ} \mathrm{N}$ a region dominated by vorticity concentra-
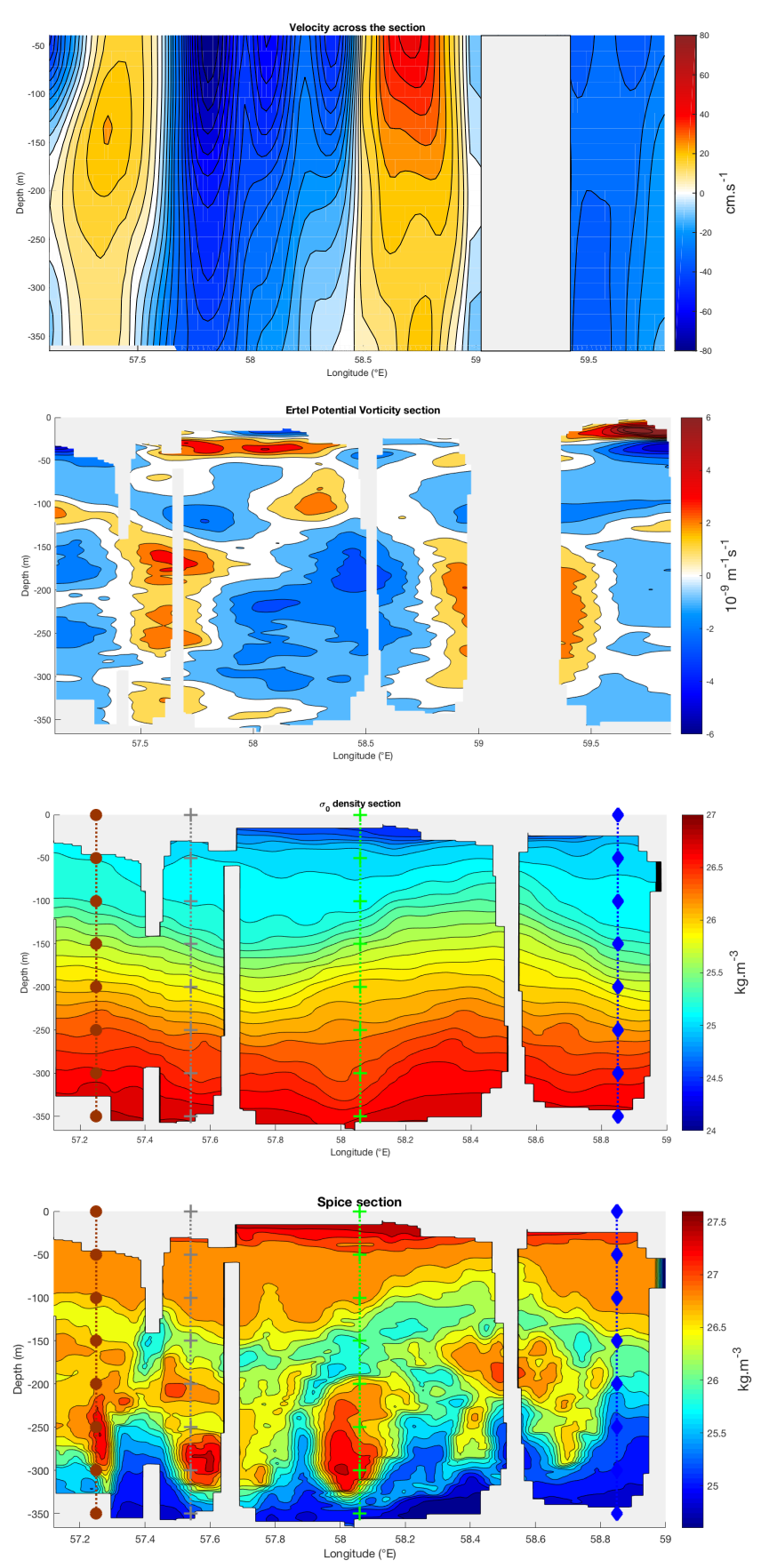

Figure 5. SO sections of the eddies, south of Ra's Al Hadd from the surface down to $350 \mathrm{~m}$ depth. Measurements and derived quantities are VM-ADCP velocities, positive towards the north; the Ertel potential vorticity anomaly is derived from VM-ADCP and SeaSoar fields; $\sigma_{0}$ potential density and spice. Profiles sampled in Fig. 7. Top panel: brown circle: cascading PGW outflow; grey cross: $57.5^{\circ} \mathrm{E}$ lens; green cross: $58^{\circ} \mathrm{E}$ lens; blue diamond: profile out of the salty outflow. 

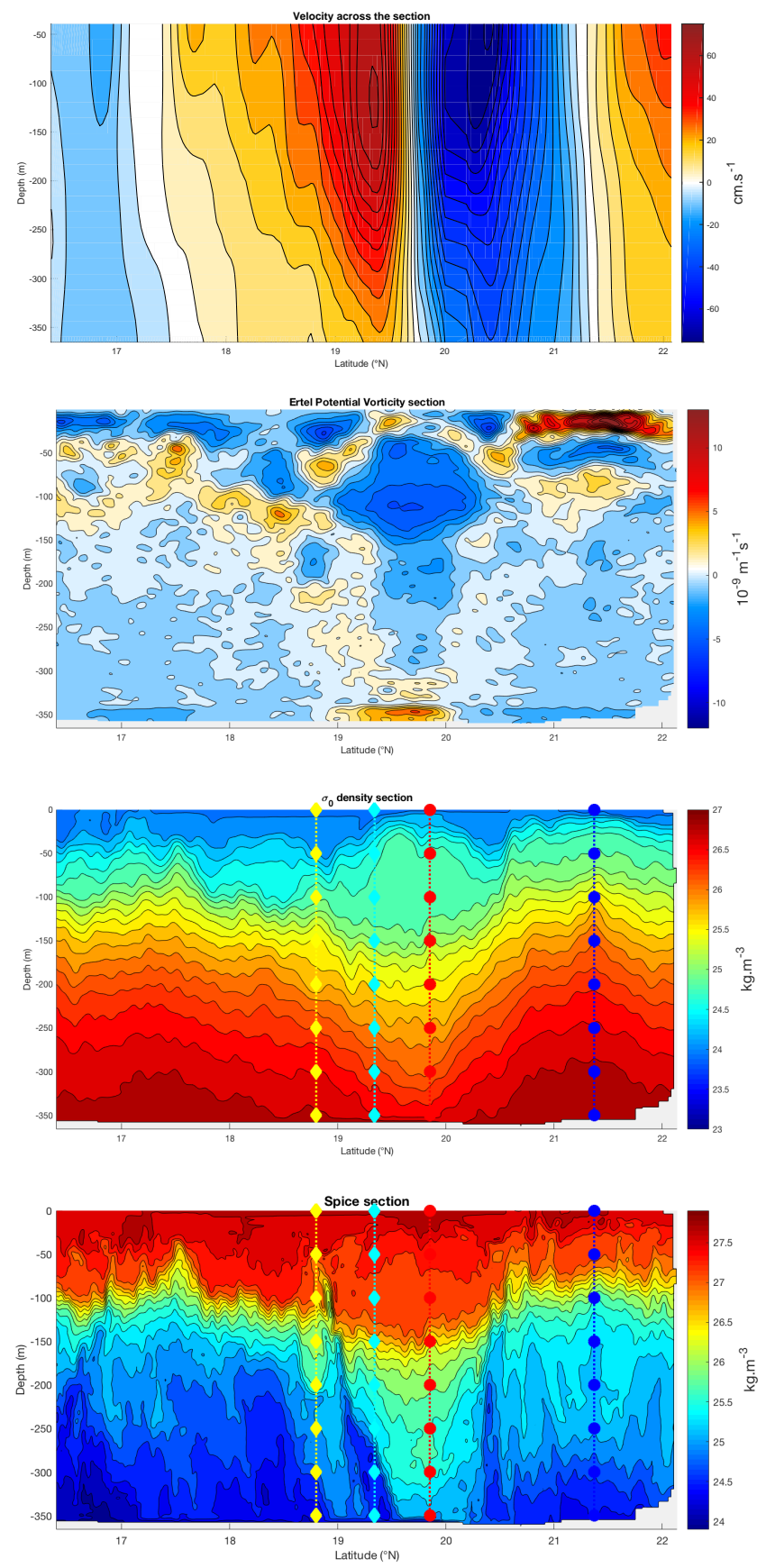

Figure 6. AS sections of the eddies, south of Ra's Al Hadd from the surface down to $350 \mathrm{~m}$ depth. Measurements and derived quantities are VM-ADCP velocities, positive towards the north; the Ertel potential vorticity anomaly is derived from VM-ADCP and SeaSoar fields; $\sigma_{0}$ potential density and spice. Profiles sampled in Fig. 8: yellow diamond: salty injection around anticyclone A2; cyan diamond: fresh injection around anticyclone A2; red circle: inside anticyclone A2; blue circle: inside cyclone $\mathrm{C} 1$. tions, and north of $20.5^{\circ} \mathrm{N}$ by deformation. Both the velocity horizontal map and the vertical section show the intensity of $\mathrm{A} 2$ and $\mathrm{C} 1$, with currents above $80 \mathrm{~cm} \mathrm{~s}^{-1}$ (upper panel, Fig. 6). Furthermore, they indicate that the eddy velocities remained noticeable below $600 \mathrm{~m}$ depth, with values above $10 \mathrm{~cm} \mathrm{~s}^{-1}$ (not shown). The density section exhibits intense lowering and rising of the isopycnals, below $\mathrm{C} 1$ and A2. In the EPV anomaly section, anticyclone A2 is clearly identified, with a negative core between 50 and $150 \mathrm{~m}$ depth.

The spice section (bottom panel of Fig. 6) displays less turbulence than that in the Sea of Oman; nevertheless, a few structures are of interest. Below the surface, isopycnal spacing is observed at $18.8^{\circ} \mathrm{N}$ at $160 \mathrm{~m}$ depth (yellow line), related to a spicier structure, characteristic of a PGW lens, with a diameter of $40 \mathrm{~km}$. Also, less spicy water wraps and flows upward along the eddies, as noted at $19.4^{\circ} \mathrm{N}$ (cyan line). The PGW containing eddies stirs and advects upward IOCW.

In the Sea of Oman, the outflowing PGW is subject to strong mixing, and is fragmented, with detached lenses at depth and more isolated patches above. In the Arabian Sea, the eddies can advect PGW in their core. Water masses at their rim undergo a strong deformation. The following sections focus on $\mathrm{PGW}$ recording during the experiment, its pathway, structure and evolution.

\section{PGW characteristics, pathways and submesoscale structures}

Table 1 indicates the peak thermohaline values of the PGW (from climatology) as it flows out of the Strait of Hormuz. The highest densities (above $26.6 \mathrm{~kg} \mathrm{~m}^{-3}$ ) are found from January to May, with a salinity well above 38 psu. This density decreases below $26 \mathrm{~kg} \mathrm{~m}^{-3}$ in late summer (JulyAugust) and early winter (October-November) as the outflow becomes fresher. The value of the PGW density is thus highly seasonal.

\subsection{Sea of Oman}

The upper panels from Fig. 7 present the thermohaline characteristics at different locations. All the profiles indicate salinity above $37.8 \mathrm{psu}$, except for the profile at the western edge of A1 (blue crosses). All of them peak in salinity at $\sigma_{0}=26.3-26.4 \mathrm{~kg} \mathrm{~m}^{-3}$, characteristic of PGW. A second peak in salinity is found at $\sigma_{0}=25.8 \mathrm{~kg} \mathrm{~m}^{-3}$, rarely above $37 \mathrm{psu}$; it can be observed in the grey profile (located in the spice section: bottom panel of Fig. 5). This more dilute PGW is well marked in the blue profile; it a priori originated from the outflow during a previous season, and must have recirculated at the western end of the Sea of Oman, as observed in a numerical simulation (L'Hégaret et al., 2015).

The coastal outflow of PGW appears on the brown and red profiles (upper panels of Fig. 7). They display wide peaks at $\sigma_{0}=26.3-26.4 \mathrm{~kg} \mathrm{~m}^{-3}$ at $37.9 \mathrm{psu}$. To the south, a thin- 
Table 1. Maximal PGW density and associated salinity and temperature, before cascading in the Sea of Oman for each month extracted from the GDEM climatology.

\begin{tabular}{lrrrrrr}
\hline Month & January & February & March & April & May & June \\
\hline Density $\left(\mathrm{kg} \mathrm{m}^{-3}\right)$ & 26.62 & 26.61 & 26.82 & 26.95 & 26.92 & 26.32 \\
Salinity $(\mathrm{psu})$ & 38.46 & 38.26 & 38.29 & 38.48 & 38.50 & 37.89 \\
Temperature $\left({ }^{\circ} \mathrm{C}\right)$ & 22.79 & 22.31 & 21.66 & 21.70 & 21.87 & 22.33 \\
\hline Month & July & August & September & October & November & December \\
\hline Density $\left(\mathrm{kg} \mathrm{m}^{-3}\right)$ & 25.91 & 26.01 & 26.25 & 26.01 & 25.74 & 26.34 \\
Salinity $(\mathrm{psu})$ & 37.53 & 37.63 & 37.83 & 37.66 & 37.32 & 38.29 \\
Temperature $\left({ }^{\circ} \mathrm{C}\right)$ & 22.80 & 22.74 & 22.42 & 22.78 & 22.84 & 23.32 \\
\hline
\end{tabular}
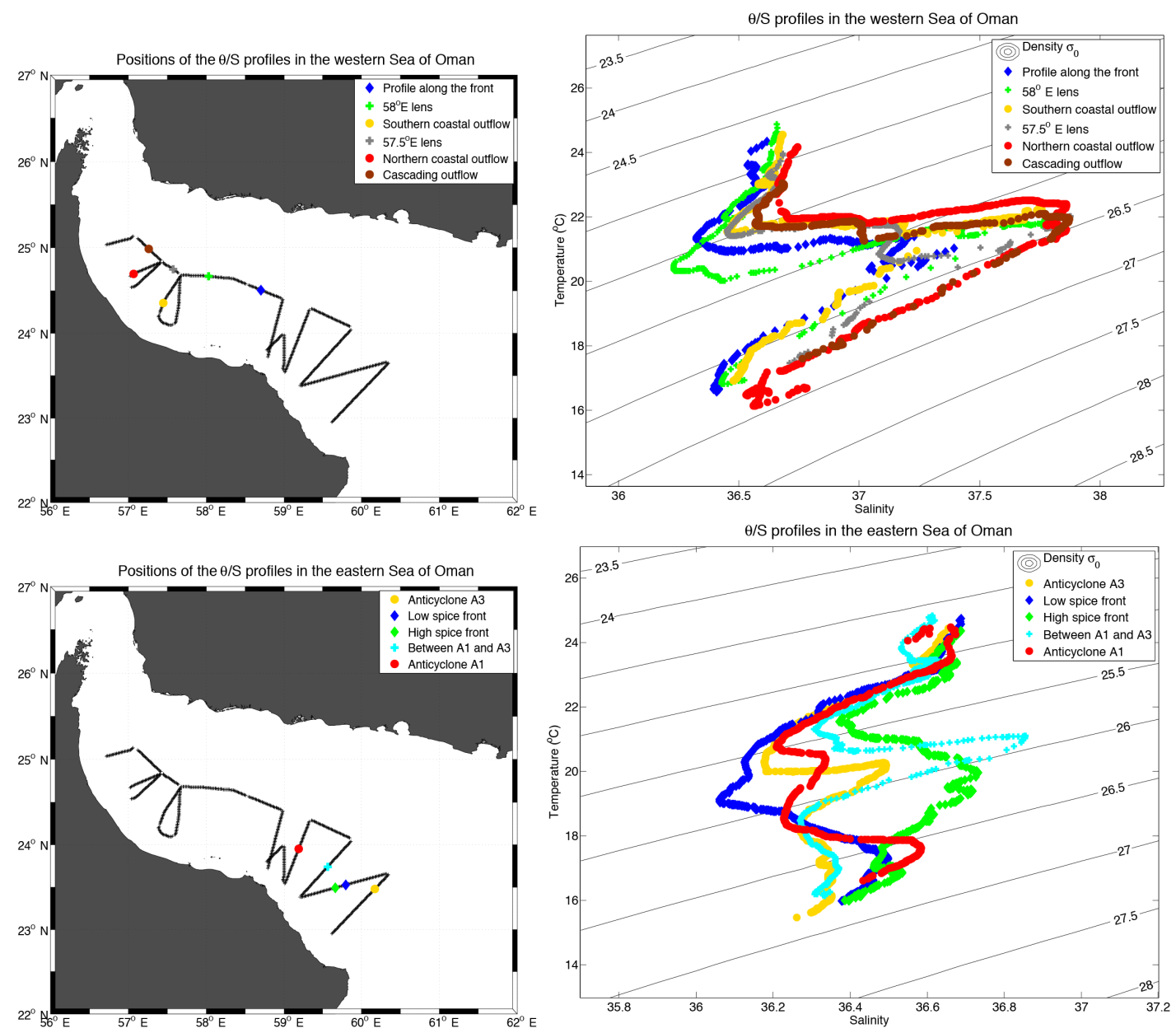

Figure 7. Potential temperature over salinity profiles (right) and their locations of interest (left); in the western Sea of Oman (top) and eastern Sea of Oman (bottom). Top panel: blue diamond: profile out of the salty outflow; green cross: $58^{\circ} \mathrm{E}$ lens; yellow circle: southern profile in the PGW outflow along the coastal slope; grey cross: $57.5^{\circ} \mathrm{E}$ lens; red circle: northern profile in the PGW outflow along the coastal slope; brown circle: cascading PGW outflow. Bottom panel: yellow circle: profile inside anticyclone A3; blue diamond: low spice profile, observed in the periphery of A3; green diamond: high spice profile, observed in the periphery of A3; cyan cross: at the periphery of anticyclones A1 and A3; red circle: profile inside anticyclone A1. 

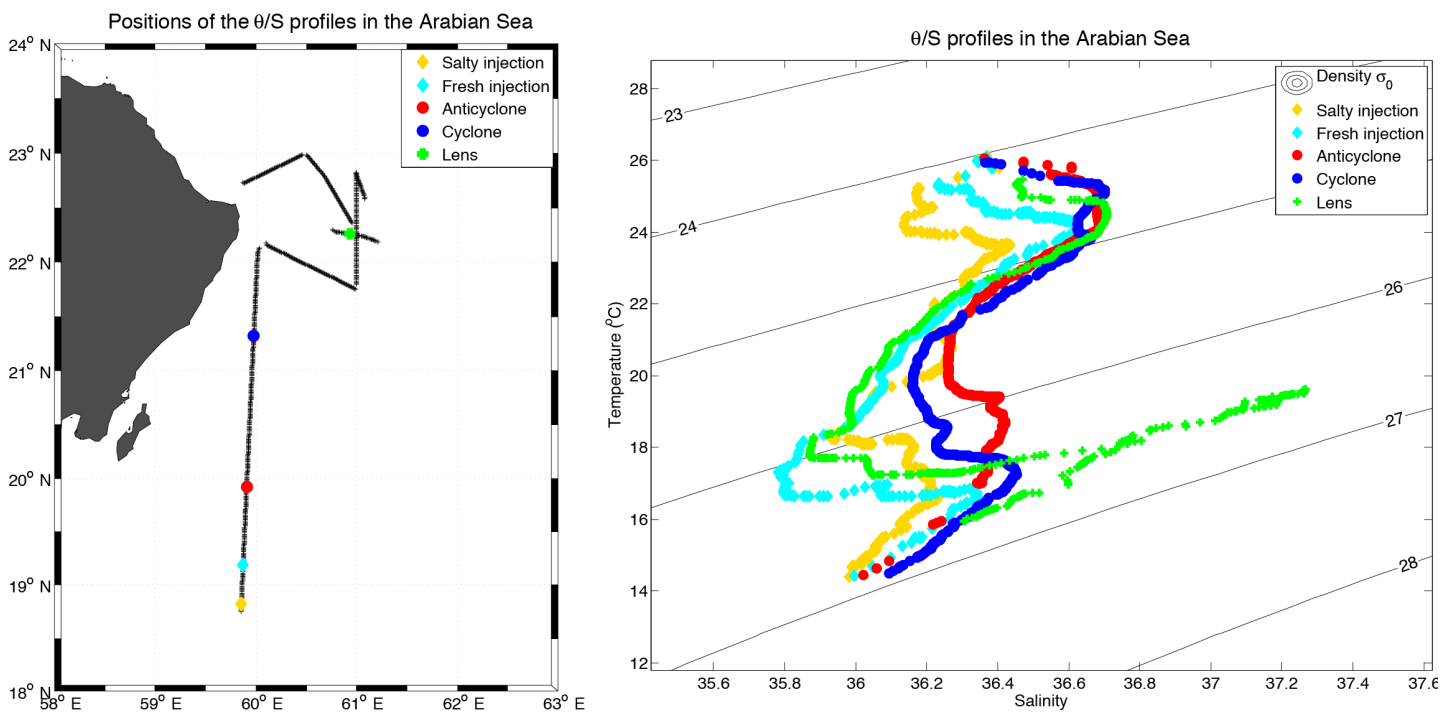

Figure 8. Potential temperature over salinity profiles (right) in the western Arabian Sea at various locations of interest (left). From north to south: yellow diamond: salty injection around anticyclone A2; cyan diamond: fresh injection around anticyclone A2; red circle: inside anticyclone A2; blue circle: inside cyclone C1; green cross: inside the lens off Ra's Al Hadd.

ner salinity peak corresponds to PGW mixing with IOCW; a peak of lighter PGW is observed at $\sigma_{0}=25.8 \mathrm{~kg} \mathrm{~m}^{-3}$ with salinity at $37.2 \mathrm{psu}$. Both profiles across the PGW lenses peak in salinity at $\sigma_{0}=26.4 \mathrm{~kg} \mathrm{~m}^{-3}$, as the core of these structures is preserved from dilution.

Above the lens at $57.5^{\circ} \mathrm{E}$, a patch of $\mathrm{PGW}$ at $\sigma_{0}=$ $25.8 \mathrm{~kg} \mathrm{~m}^{-3}$ with salinity of $37.2 \mathrm{psu}$ is found. The lens at $57.5^{\circ} \mathrm{E}$ (grey profile) had a diameter of $15 \mathrm{~km}$, a height of $50 \mathrm{~m}$, and advecting diluted PGW above it, while the lens at $58^{\circ} \mathrm{E}$ (green profile) had a diameter of $25 \mathrm{~km}$ and a height of $100 \mathrm{~m}$. The first one must have formed earlier, probably in early winter, recirculating and slowly eroding in the western Sea of Oman, whereas the second must have formed later.

The bottom panels of Fig. 7 present thermohaline profiles in the eastern Sea of Oman. The red and yellow profiles show the different characteristics of the PGW trapped in anticyclones A1 and A3. Anticyclone A3 was formed between February and March 2011 and had only one extremum of PGW salinity at $\sigma_{0}=25.8 \mathrm{~kg} \mathrm{~m}^{-3}$ (see Fig. 3). Anticyclone A1 formed in December 2010, and enclosed two PGW maxima (see red profile): the first maximum corresponds to waters denser than those recorded in the western Sea of Oman, below $\sigma_{0}=26.6 \mathrm{~kg} \mathrm{~m}^{-3}$; the second maximum was more diluted, at $\sigma_{0}=25.6 \mathrm{~kg} \mathrm{~m}^{-3}$, and was lighter than that observed in A3. Thus, during its formation, anticyclone A1 enclosed two PGW patches from different seasons.

\subsection{Arabian Sea}

Figure 8 presents thermohaline profiles in the Arabian Sea. Cyclone $\mathrm{C} 1$ (blue profile) formed at the same period as anticyclone A1, in December 2010 or early January 2011 (see Fig. 3). Similarly, it shows a peak of PGW at $\sigma_{0}=$
$26.6 \mathrm{~kg} \mathrm{~m}^{-3}$, slightly more diluted, $0.2 \mathrm{psu}$, below A1 as it lay downstream.

Anticyclone A2 (red profile in Fig. 8) formed 1 month later, between January and February 2011. Inside it, the PGW peak was less marked and wider: this water mass mixed with the surrounding IOCW. The density ranged from 26 to $26.3 \mathrm{~kg} \mathrm{~m}^{-3}$, indicating PGW flowing out of the Persian Gulf from early 2010 or late summer 2010 .

The cyan and yellow profiles in Fig. 8 focus on the layers wrapping around anticyclone A2 and located at its southern edge. The cyan profile indicates that IOCW, with salinity below $35.8 \mathrm{psu}$, in the density range of the PGW, was advected and tilted around the eddy rim. The yellow profile crossed PGW just below the thermocline (see density density section, Fig. 6); the salinity peak is found at $25.5 \mathrm{~kg} \mathrm{~m}^{-3}$. This light PGW is comparable to that observed in the core of A3 (see bottom panel Fig. 7, yellow profile) but with a weaker salinity; thus, it formed farther from the Sea of Oman. This PGW was advected around A2, also with a tilted structure.

\subsection{Submesoscale lens off Ra's Al Hadd}

The lens section displayed in Fig. 4 corresponds to the measurements performed between 19 and 20 March 2011. This section extended between anticyclone A3 and cyclone C1 and recorded a submesoscale lens of PGW. The surface fields indicate westward geostrophic velocities, above $0.4 \mathrm{~m} \mathrm{~s}^{-1}$, in a region dominated by deformation.

The velocity section (Fig. 9, top) shows the westward velocities from the surface down to $200 \mathrm{~m}$ depth, intensifying up to $0.8 \mathrm{~m} \mathrm{~s}^{-1}$ near cyclone $\mathrm{C} 1$. Between 22.1 and $22.4^{\circ} \mathrm{N}$, and 250 and $400 \mathrm{~m}$ depth, an anticyclonic motion is observed in the zonal velocity section with a speed of about $0.2 \mathrm{~cm} \mathrm{~s}^{-1}$, 

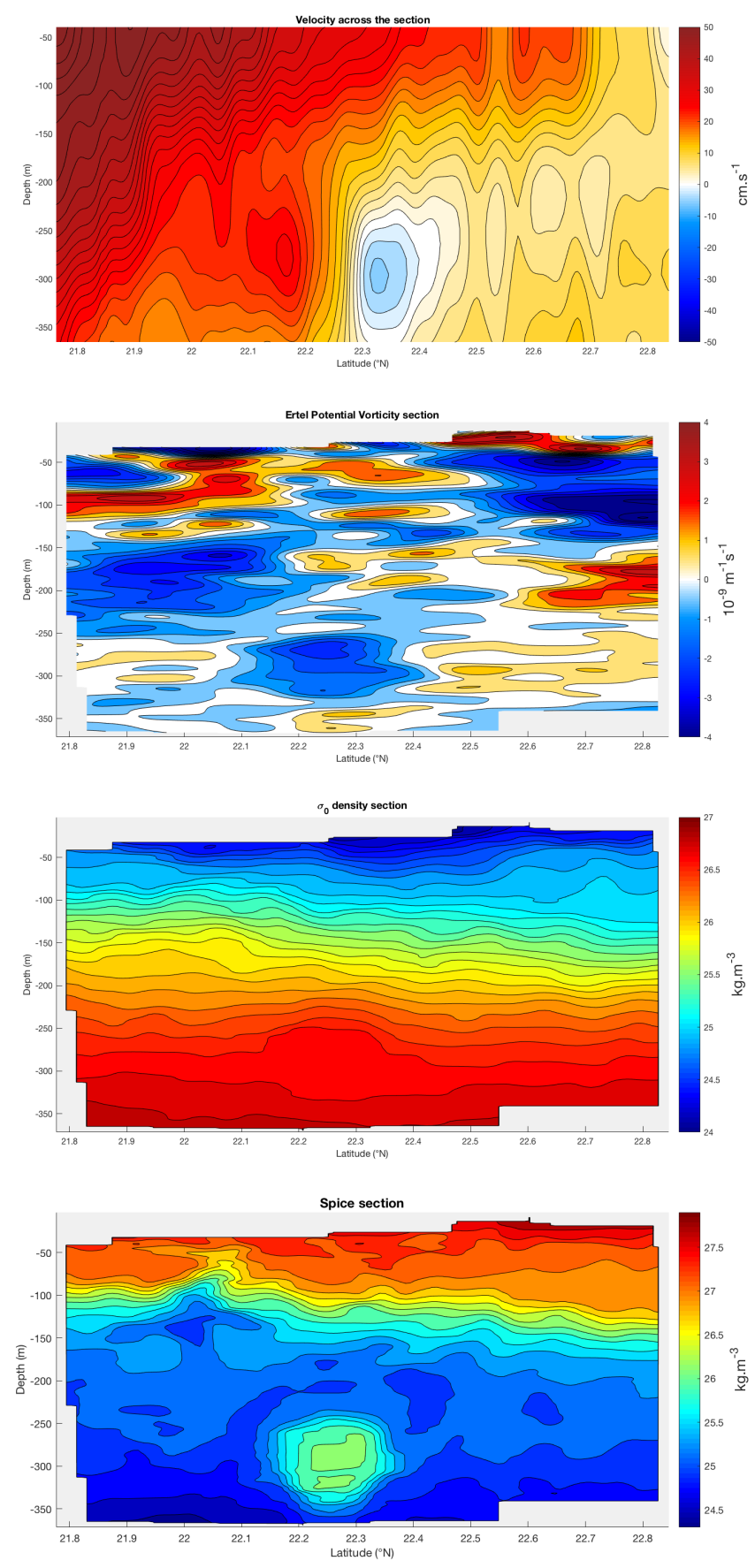

Figure 9. Sections across the lens off Ra's Al Hadd, from the surface down to $350 \mathrm{~m}$ depth. Measurements and derived quantities are VM-ADCP velocities, positive towards the north; the Ertel potential vorticity anomaly is derived from VM-ADCP and SeaSoar fields; $\sigma_{0}$ potential density and spice. The green cross profile from Fig. 8 is taken in the core of this lens.

but this signal is strongly dominated by the velocity of the surface eddy. This anticyclonic structure is also shown in the EPV anomaly field (Fig. 9) by the negative core around $300 \mathrm{~m}$ depth and by the spacing of the isopycnals.
The spice section (bottom panel of Fig. 9) confirms the presence of a lens-shaped structure between 250 and $350 \mathrm{~m}$ depth, with a diameter of $25 \mathrm{~km}$, and the green profile of Fig. 8 crossing the center of the lens indicates a temperature of $19^{\circ} \mathrm{C}$ and salinity above 37.3 psu at its center; the density is $\sigma_{0}=26.6 \mathrm{~kg} \mathrm{~m}^{-3}$.

In a perpendicular cross section (not presented here), the lens had a diameter of $33 \mathrm{~km}$; this shows that this lens was elliptical, as confirmed by a third section. The total salt and heat content, inside the $36.6 \mathrm{psu}$ (or $18^{\circ} \mathrm{C}$ ) contour, was $2.59 \times 10^{12} \mathrm{~kg}$ and $6.54 \times 10^{19} \mathrm{~J}$, and the lens volumic transport (across the section) was above $0.4 \mathrm{~Sv}$. The spice section also displays a layer of IOCW above the lens at $22.1^{\circ} \mathrm{N}$.

The peak salinity above 37.3 psu is observed only in the Sea of Oman in this period; this density corresponds to PGW that flowed out of the Strait of Hormuz in early 2011; therefore, this lens likely formed in the Sea of Oman.

In L'Hégaret et al. (2015), several mechanisms leading to the formation of eddies containing PGW were listed. Here, two possible mechanisms are assessed. In winter, lee eddies form downstream of Ra's Al Hamra; these eddies retain highsalinity water in their core before eroding for 3 months. This mechanism is observed in a high-resolution HYCOM simulation, where lee eddies are the only structures retaining salinity above $37 \mathrm{psu}$ in the Arabian Sea and possessing a strong altimetric signature. In the MADT anomaly maps between January and March 2011, no such signature was observed; this renders these mechanisms rather unlikely here.

The other mechanism for the formation of this lens in the Sea of Oman would be the ejection of PGW fragments from the coastal outflow under the action of mesoscale eddies. This can occur near Ra's al Hamra in late winter or early spring, or south of Ra's Al Hadd. In the Sea of Oman, the maximal deformation affecting the PGW outflow occurred near Ra's Al Hamra. This mechanism implies that the PGW lens would have drifted about $600 \mathrm{~km}$, around anticyclone A2. The anticyclone velocity was at least $0.4 \mathrm{~m} \mathrm{~s}^{-1}$ at the depth of the outflow; therefore, the lens would have taken 15 days to travel this distance; this would lead to a lens formation in early March, coherent with the PGW density in the core of the lens. Another possible formation site is south of Ra's Al Hadd. Cyclone C1 would have ejected the lens and advected it. With a velocity of about $0.6 \mathrm{~m} \mathrm{~s}^{-1}$, it would have taken 10 days between ejection and the Phys-Indien measurements. Nevertheless, the salinity and density of the lens were higher than those of the PGW outflow near Ra's Al Hadd. Therefore, lens formation near Ra's al Hamra was more likely.

During the Phys-Indien 2011 experiment, two deep drogued Surdrift floats and three ARGO floats were seeded in this submesoscale lens. The Surdrift floats allow hourly tracking of the lens, and the ARGO floats record temperature and salinity with a surfacing every 5 days. All these floats followed a northwestward trajectory for the first 4 days of measurements. After this period, the three ARGO floats were 

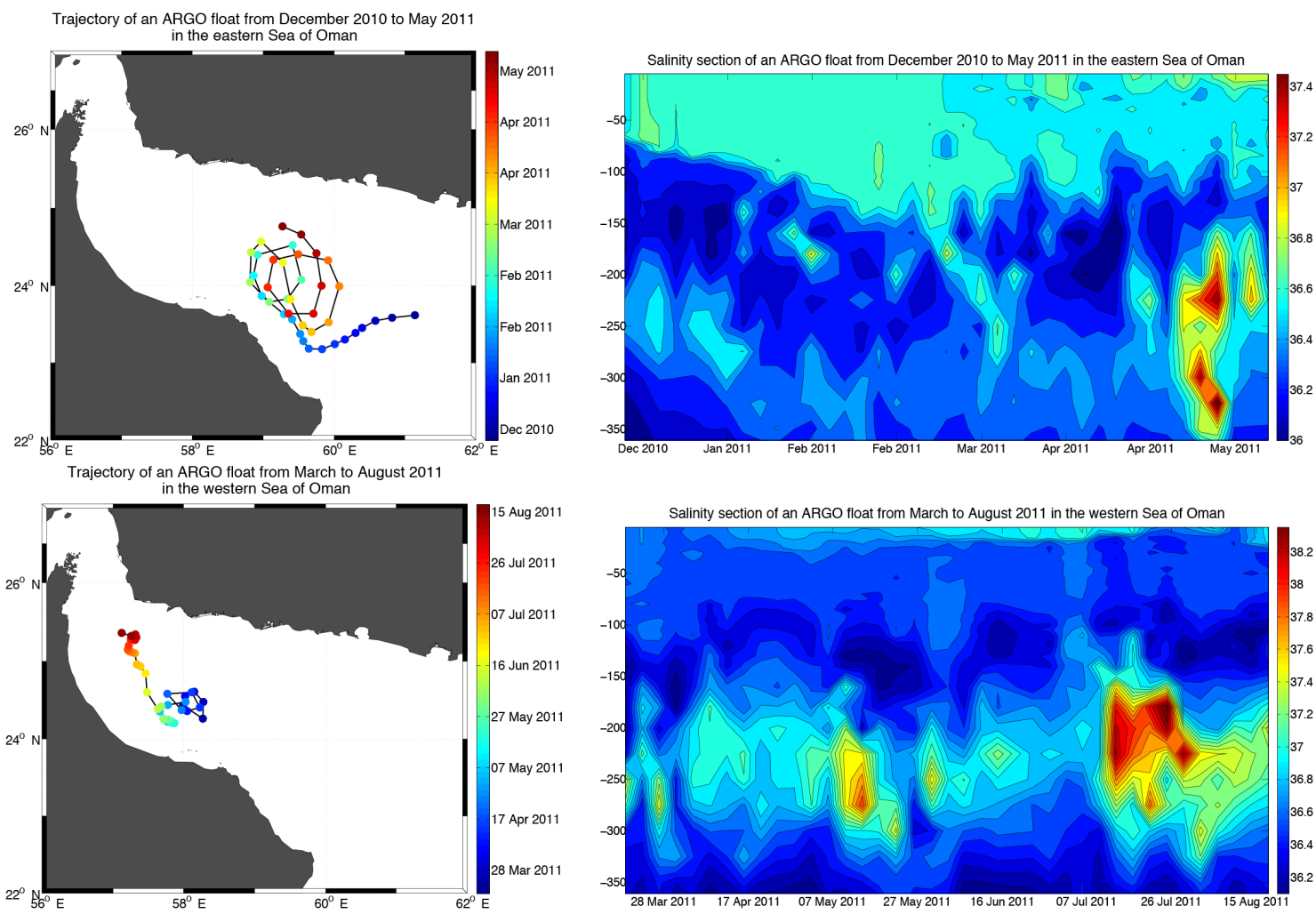

Figure 10. ARGO floats 2901370 (top) and 2901387 (bottom), trajectories (left) and salinity sections (right) in the eastern and western Sea of Oman. Float 2901370 (up) enters the Sea of Oman with anticyclonic loops, is stopped by the front in March 2011 and then looped cyclonically until late May 2011, between A1 and A3. Float 2901387 looped cyclonically from March to May 2011 before moving northwest. Patches of salty PGW are observed, with the strongest in July, when the float is found near the position of cascading PGW.

ejected, as revealed by their recorded salinity; so were the surdrifts, which then followed anticyclone A3, north of Ra's Al Hadd. One Surdrift buoy lost its drogue and performed inertial loops. This inability to track the lens for long durations underlines the strong deformation that it was subjected to.

The deformation of a lens by external shear or strain was studied by Ruddick (1987): as strain increases, the lens becomes more elliptical and unsteady, before either breaking up or readjusting. And indeed, this submesoscale lens off Ra's $\mathrm{Al}$ Hadd was elliptical and embedded in a strong deformation field due to the strong mesoscale eddies in its vicinity. Walsh (1995) studied the deformation of a lens in a uniform large-scale shear in a model. With $q$ the potential vorticity of the lens, $S$ the external shear, and $a$ and $b$ the long and short axes of the ellipse, the theoretical lateral deformation of the eddy is

$\frac{a-b}{a+b}=\frac{15}{8} \frac{S}{q}$,

with $a=33 \mathrm{~km}$ and $b=20 \mathrm{~km} ; S=0.1 q$. The potential vorticity of the lens was about $8 \times 10^{-5} \mathrm{~s}^{-1}$, leading to $S \sim$ $10^{-5} \mathrm{~s}^{-1}$. At the depth of the lens, the mesoscale eddies velocities and radius gave a measured shear of $\frac{\partial V}{\partial r} \sim \frac{V}{R} \sim$ $\frac{0.5}{50 \times 10^{3}} \sim 10^{-5} \mathrm{~s}^{-1}$, the same magnitude as calculated with the Walsh (1995) model.

\subsection{Recurrence of PGW lenses}

Numerous ARGO floats (with WHOI numbers 2901370 and 2901387, displayed in Fig. 10, or WHOI numbers 1901187, 1901202 and 6900902) sampled PGW in the Sea of Oman. Until the early summer monsoon, localized patches of PGW with salinity above $37.2 \mathrm{psu}$, temperature around $20^{\circ} \mathrm{C}$ and $\sigma_{0} \approx 26.5 \mathrm{~kg} \mathrm{~m}^{-3}$ are observed, with a spacing of the isopycnals above and below them. These patches are found either off Ra's Al Hadd or off the Sea of Oman.

In June 2011, anticyclone A3 was advected northward as the summer monsoon began, thus reducing the deformation field off Ra's Al Hamra. To break the PGW outflow into lenses and filaments, Vic et al. (2015), using a highresolution numerical model, showed that a strong shear and strain is necessary. Thus fewer submesoscale PGW structures are expected to be observed during the summer monsoon (when the deformation field is less intense), but due to a lack of regular observations at the depth of PGW. Note that another possible mechanism for PGW outflow breaking is baroclinic instability, which depends on the vertical shear of 


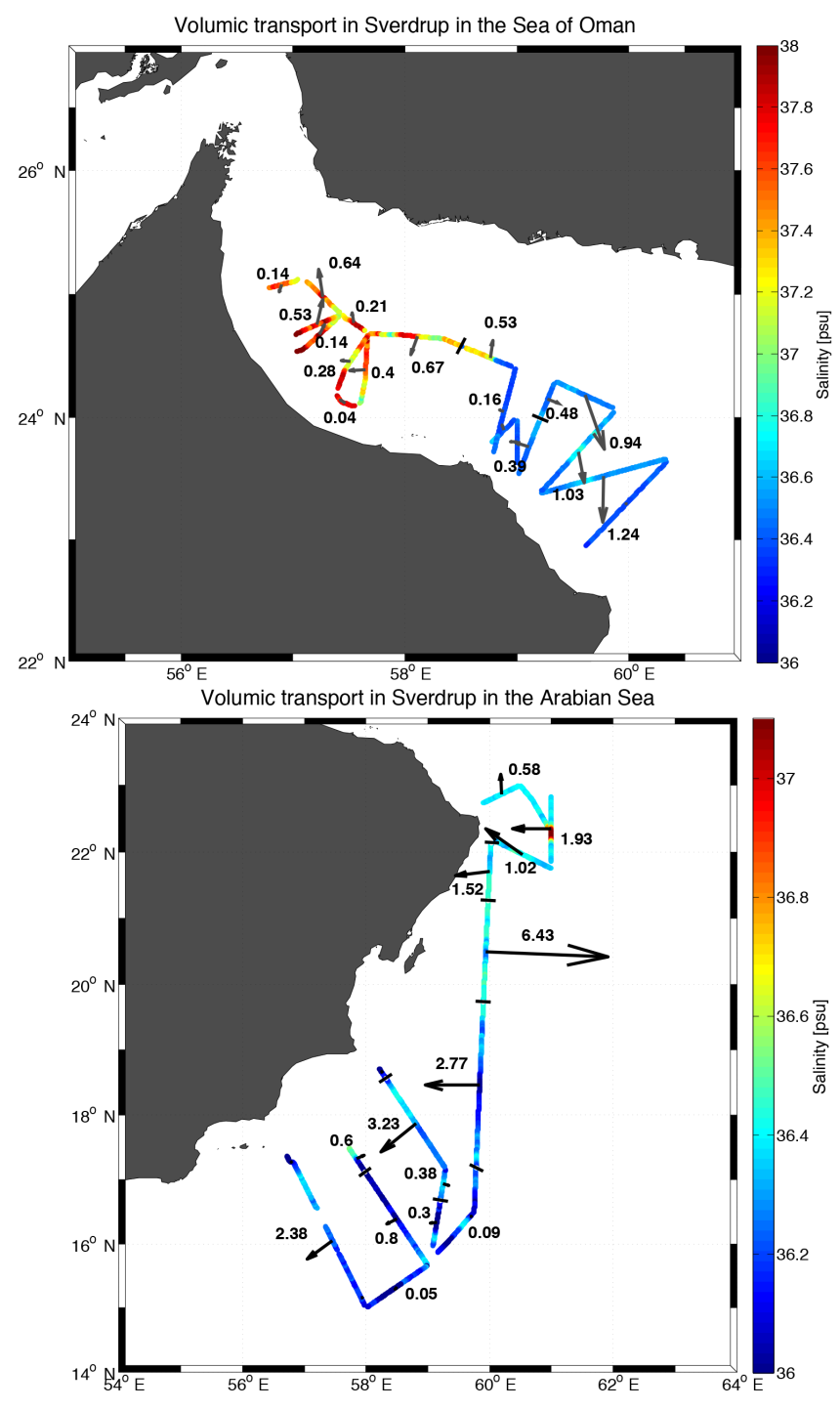

Figure 11. Eulerian volumic transport across the SeaSoar/VMADCP sections in the Sea of Oman (top) and in the Arabian Sea (bottom). Arrows indicate the direction, the values are in Sverdrup, and in color is indicated the maximum of the salt in the PGW layer.

velocity. This speed should also be recorded regularly on the continental slope near Ra's al Hamra. Baroclinic instability has been mentioned by Pous et al. (2004) to explain fragment detachment from the outflow in fall 1999 (during the GOGP1999 experiment).

\subsection{Synthetic view of the PGW pathway and characteristics}

Maps of Eulerian transport (Fig. 11) are computed to follow the pathways of the PGW outflow. The Eulerian transport directions can be related to the in situ velocity sections and to the altimetric maps (surface currents) already presented. Indeed, in the Sea of Oman, the volumic transport was anticy- clonic, with two cells, between 57 and $58.5^{\circ} \mathrm{E}$ and between 58.5 and $60^{\circ} \mathrm{E}$. This corresponded to A1 and A3. In the Arabian Sea, the strong jet between $\mathrm{C} 1$ and $\mathrm{A} 2$ led to the eastward $6.4 \mathrm{~Sv}$ transport at $20.5^{\circ} \mathrm{N}$, while an opposite westward jet between $\mathrm{A} 2$ and $\mathrm{C} 2$ at $18^{\circ} \mathrm{N}$ transported $2.8 \mathrm{~Sv}$.

Figure 12 indicates that, in the Sea of Oman, the front already seen in the SO section appeared with warm and salty PGW west of $59^{\circ} \mathrm{E}$, and fresher waters with patches of higher spice east of $59^{\circ} \mathrm{E}$. This front, created by the strong anticyclone A1 and a cyclone west of it, halted the zonal spreading of the PGW and advected it northward. The penetrating IOCW was also blocked from the east by the front, as observed on the recording of an ARGO float (number 2901370) in March 2011 (see Fig. 10).

In the western Sea of Oman, newly outflowing PGW cascaded down the southern continental slope, where the saltiest PGW was observed. In late March, the anticyclonic circulation of the basin drove the water westwards (see transport Fig. 11, top). This motion was observed on an ARGO float (number 2901387; see Fig. 10), looping cyclonically from March to May, then moving northwestward, towards the strait. This recirculation, associated with that induced by A1, forced PGW to remain in the western part of the basin; therefore, PGW from two different seasons was present in the same region. This was confirmed by the map of the PGW density (bottom left panel of Fig. 12) with various values in the western basin. This was also noticed in the blue and green profiles of Fig. 7, where two neighboring samples have different characteristics.

Furthermore, fragmented PGW was found at the periphery of A1 and A3 (see bottom panel of Fig. 7, cyan profile); this peripheral PGW had high salinity, but it was more diluted in the core of these eddies; Fig. 7 (bottom, red profile) showed a difference of about 0.8 psu between the periphery and the core; this might be due to the intrusion mechanism of PGW into the core, or to earlier mixing with fresher, colder IOCW. The recent, denser PGW from winter was mainly observed in A1, whereas older, mixed and lighter PGW is found in A3.

In March 2011, the PGW mainly exited the Sea of Oman along its northern boundary, circling around anticyclones, but small patches below 36.8 psu were observed, confined to the southern coast between Ra's Al Hamra and Ra's Al Hadd (see the green profile in the bottom panel of Fig. 7). The PGW density there ranged from 25.6 to $26.3 \mathrm{~kg} \mathrm{~m}^{-3}$; this indicates mixed PGW from different seasons with IOCW trapped between A1, A3 and the coast; indeed, this small regional dynamics was dominated by deformation (bottom left panel of Fig. 3, southeast of Ra's Al Hamra).

In the Arabian Sea, the PGW evolution around eddies C1 and A2 was similar to that in the Sea of Oman, but with stronger dilution, by more than 1 psu (see Fig. 8). In anticyclone A2, the PGW layer was warmer (top left panel of Fig. 12), with temperature above $19.5^{\circ} \mathrm{C}$; this was a priori due to heat transfer from the ASHSW layer in this intense 

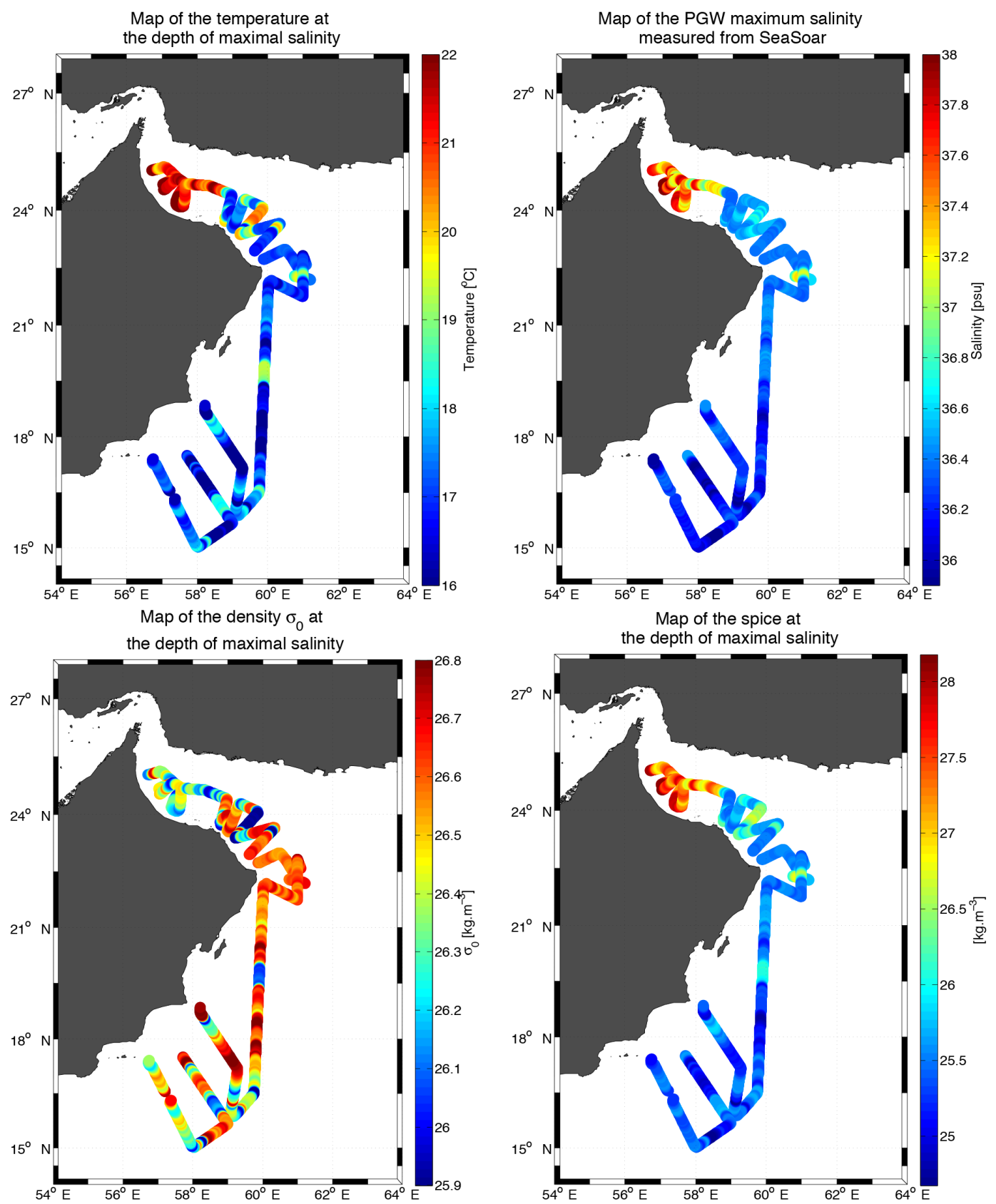

Figure 12. Maximal thermohaline characteristics of the Persian Gulf Water (from the SeaSoar measurements, for $\sigma_{0}$ between 26 and 26.7 ). The variables are temperature (top, left), salinity (top, right), $\sigma_{0}$ at the maximal salinity depth (bottom, left), and spice at the same depth (bottom, right).

eddy. South of $18^{\circ} \mathrm{N}$, the PGW was strongly diluted and mixed with the IOCW.

Both in the Arabian Sea and in the Sea of Oman, layers of colder and fresher IOCW were wrapped around the strong mesoscale eddies, and around the submesoscale lens (cyan profile, bottom panel of Fig. 8). These structures presented no front in density but a marked one in spice (see Fig. 6). Smith and Ferrari (2009) suggested that these filaments could result from the stirring by the mesoscale eddies. The slope of the fresher injections around anticyclone A2 (on the AS section in Fig. 6) are compared with the $f / N$ ratio and with the strain over shear ratio induced by the eddies.

The isospice slope varies from $3 \times 10^{-3}$ to $4 \times 10^{-3},-f / N$ from $6 \times 10^{-3}$ to $7 \times 10^{-3}$, and $-(\mathrm{d} U / \mathrm{d} x) /(\mathrm{d} U / \mathrm{d} z)$ from $3 \times 10^{-3}$ to $4 \times 10^{-3}$. This suggests that stirring could produce these tilted layers. Furthermore, the presence of these colder and fresher injections below warmer and saltier PGW could favor double diffusion. 


\section{Discussion and conclusion}

The Phys-Indien experiment took place in March 2011, in the Arabian Sea and in the Sea of Oman, during the spring intermonsoon. The surface dynamics was dominated by mesoscale eddies along the western coast of the Arabian Sea. A strong mesoscale anticyclone was observed in the eastern part of the Sea of Oman, characteristic of the spring intermonsoon. These eddies are observed in the monthly sealevel climatologies from satellite altimetry with the same sizes, but with a stronger intensity in 2011, in particular the cyclone south of Ra's Al Hadd. Nevertheless, the eddies from March 2011 showed surface velocities comparable in intensity to the HYCOM model used in L'Hégaret et al. (2015).

Vertical sections of velocities, obtained with a VM-ADCP, showed that these energetic mesoscale eddies have a deep dynamical influence; they tilt the water masses around them (IOCW and PGW). Inside the cores of these eddies, these water masses retain the thermohaline characteristics they had at the time of their trapping. PGW filaments wrapping around these eddies are subject to mixing. Besides, tilted layers, primarily of cold and fresh IOCW, are observed around the eddies; this can induce mixing and dilution of the highly saline waters.

In the western Sea of Oman, the PGW outflow appears fragmented, forming small eddies, filaments and a few isolated patches. Two layers of PGW, with different densities, from the winter monsoon and earlier mixed PGW, were observed at the same location, due to the anticyclonic recirculation of PGW in the western basin. The PGW outflow was not observed in the measurements along the coast between Ra's Al Hamra and Ra's al Hadd, with the exception of a few small coastal patches; most PGW was advected north, around anticyclones $\mathrm{A} 1$ and $\mathrm{A} 3$, slowly diluting along its pathway, with a salinity below 37 psu. A similar situation was observed in the HYCOM simulation from L'Hégaret et al. (2015) (Figs. 21 and 22) with an ejection at Ra's Al Hamra with a difference of 0.6 psu between the front of the ejection and the surrounding waters, comparable to the observations from the SeaSoar. Also, a coastal branch of PGW was found in the model between Ra's Al Hadd and Ra's Al Hamra, with salinity up to $36.8 \mathrm{psu}$, as observed in the profiles from March 2011.

A submesoscale lens recorded off Ra's Al Hadd possessed strong salinity (over $37 \mathrm{psu}$ ) and temperature, characteristic of the winter monsoon. Different hypotheses were proposed for its formation; most likely, this lens can have been formed by the fragmentation of the PGW outflow, by the mesoscale eddies, at Ra's Al Hamra, 15 days before the sampling of the lens. This submesoscale lens was located between two mesoscale eddies during the Phys-Indien experiment, and had an elliptical structure. These mesoscale eddies deformed the lens, making it unsteady, and float trajectories suggest that it rapidly disappeared afterwards. The shear and strain of the mesoscale eddies that contributed to form the lenses also led to their disappearance.

Thus, spring presents favorable conditions for PGW lens detection, with their ejection from the coastal outflow, and their advection around mesoscale eddies. During the summer monsoon, the PGW outflow is expelled by the Ra's Al Hadd jet, an intense mesoscale dipole, which may form but also disrupt PGW lenses. In March 2014, a second PhysIndien experiment took place around the Arabian Peninsula; the comparison between the results of the two experiments will be the subject of a forthcoming study.

Acknowledgements. Pierre L'Hégaret thanks DGA (French Ministry of Defence) and the Brittany region for his $\mathrm{PhD}$ grant. Xavier Carton acknowledges support from ANR DGA under the Synbios project of the Astrid program. The authors are grateful to the two anonymous referees whose suggestions and remarks greatly improved the contents of this paper.

Edited by: P. Chapman

\section{References}

Al Saafani, M., Shenoi, S., Shankar, D., Aparna, M., Kurian, J., Durand, F., and Vinayachandran, P.: Westward movement of eddies into the Gulf of Aden from the Arabian Sea, J. Geophys. Res.Oceans, 112, C11004, doi:10.1029/2006JC004020, 2007.

Banse, K.: Irregular flow of Persian (Arabian) Gulf water to the Arabian sea, J. Marine Res., 55, 1049-1067, 1997.

Barth, J. A., O'Malley, R. T., Fleischbein, J., Smith, R. L., and Huyer, A.: SeaSoar and CTD observations during coastal jet separation cruise W9408A, August to September 1994, Tech. rep., College of Oceanic and Atmospheric Sciences, Corvallis, OR, USA, 1996.

Bower, A. S. and Furey, H. H.: Mesoscale eddies in the Gulf of Aden and their impact on the spreading of Red Sea Outflow Water, Prog. Oceanogr., 96, 14-39, 2012.

Bower, A. S., Hunt, H. D., and Price, J. F.: Character and dynamics of the Red Sea and Persian Gulf outflows, J. Geophys. Res.Oceans, 105, 6387-6414, 2000.

Carton, X., L'Hegaret, P., and Baraille, R.: Mesoscale variability of water masses in the Arabian Sea as revealed by ARGO floats, Ocean Sci., 8, 227-248, doi:10.5194/os-8-227-2012, 2012.

Chelton, D. B., Deszoeke, R. A., Schlax, M. G., El Naggar, K., and Siwertz, N.: Geographical variability of the first baroclinic Rossby radius of deformation, J. Phys. Oceanogr., 28, 433-460, 1998.

Findlater, J.: A major low-level air current near the Indian Ocean during the northern summer, Q. J. Roy. Meteor. Soc., 95, 362380, 1969.

Fischer, A. S., Weller, R. A., Rudnick, D. L., Eriksen, C. C., Lee, C. M., Brink, K. H., Fox, C. A., and Leben, R. R.: Mesoscale eddies, coastal upwelling, and the upper-ocean heat budget in the Arabian Sea, Deep-Sea Res. Pt. II, 49, 2231-2264, 2002.

Hoskins, B.: The role of potential vorticity in symmetric stability and instability, Q. J. Roy. Meteor. Soc., 100, 480-482, 1974. 
IOC, SCOR and IAPSO: The international thermodynamic equation of seawater - 2010: calculation and use of thermodynamic properties, Intergovernmental Oceanographic Commission, Manuals and Guides No. 56, UNESCO (English), 196 pp., 2010.

Kumar, S. P. and Prasad, T.: Formation and spreading of Arabian Sea high-salinity water mass, J. Geophys. Res.-Oceans, 104, 1455-1464, 1999.

Lee, C. M., Jones, B. H., Brink, K. H., and Fischer, A. S.: The upper-ocean response to monsoonal forcing in the Arabian Sea: seasonal and spatial variability, Deep-Sea Res. Pt. II, 47, 1177 1226, 2000.

L'Hégaret, P., Lacour, L., Carton, X., Roullet, G., Baraille, R., and Corréard, S.: A seasonal dipolar eddy near Ras Al Hamra (Sea of Oman), Ocean Dynam., 63, 633-659, 2013.

L'Hégaret, P., Duarte, R., Carton, X., Vic, C., Ciani, D., Baraille, R., and Corréard, S.: Mesoscale variability in the Arabian Sea from HYCOM model results and observations: impact on the Persian Gulf Water path, Ocean Sci., 11, 667-693, doi:10.5194/os-11667-2015, 2015.

Lueck, R. G. and Picklo, J. J.: Thermal inertia of conductivity cells: observations with a Sea-Bird cell, J. Atmos. Ocean. Tech., 7, 756-768, 1990.

Mensah, V., Le Menn, M., and Morel, Y.: Thermal mass correction for the evaluation of salinity, J. Atmos. Ocean. Technol., 26, 665672,2008

Meshal, A. and Hassan, H.: Evaporation from the coastal water of the central part of the Gulf, Arab Gulf Journal of Scientific Research, 4, 649-655, 1986.

Pous, S., Carton, X., and Lazure, P.: Hydrology and circulation in the Strait of Hormuz and the Gulf of Oman results from the GOGP99 experiment: 2. Gulf of Oman, J. Geophys. Res.Oceans, 109, doi:10.1029/2003JC002146, 2004.

Prasad, T., Ikeda, M., and Kumar, S. P.: Seasonal spreading of the Persian Gulf Water mass in the Arabian Sea, J. Geophys. Res.Oceans, 106, 17059-17071, 2001.

Premchand, K., Sastry, J., and Murty, C.: Watermass structure in the western Indian Ocean: Part II, The spreading and transformation of the Persian Gulf Water, Mausam, 37, 179, doi:10.1029/2000JC000480, 1986.
Privett, D.: Monthly charts of evaporation from the N. Indian Ocean (including the Red Sea and the Persian Gulf), Q. J. Roy. Meteor. Soc., 85, 424-428, 1959.

Reynolds, R. M.: Physical oceanography of the Gulf, Strait of Hormuz, and the Gulf of Oman results from the Mt Mitchell expedition, Mar. Pollut. Bull., 27, 35-59, 1993.

Ruddick, B. R.: Anticyclonic Lenses in Large-Scale Strain and Shear, J. Phys. Oceanogr., 17, 741-749, doi::10.1175/15200485(1987)017<0741:ALILSS>2.0.CO;2, 1987.

Senjyu, T., Ishimaru, T., Matsuyama, M., and Koike, Y.: High salinity lens from the Strait of Hormuz, in: Offshore Environment of the ROPME Sea Area after the War-Related Oil Spill, Terra Scientific Publishing Company, Tokyo, 35-48, 1998.

Smith, K. S. and Ferrari, R.: The production and dissipation of compensated thermohaline variance by mesoscale stirring, J. Phys. Oceanogr., 39, 2477-2501, 2009.

Swift, S. A. and Bower, A. S.: Formation and circulation of dense water in the Persian/Arabian Gulf, J. Geophys. Res.-Oceans, 108, 3004, doi:10.1029/2002JC001360, 2003.

Thoppil, P. G. and Hogan, P. J.: On the mechanisms of episodic salinity outflow events in the Strait of Hormuz, J. Phys. Oceanogr., 39, 1340-1360, 2009.

Vic, C., Roullet, G., Carton, X., and Capet, X.: Mesoscale dynamics in the Arabian Sea and a focus on the Great Whirl life cycle: a numerical investigation using ROMS, J. Geophys. Res.-Oceans, 119, 6422-6443, 2014.

Vic, C., Roullet, G., Capet, X., Carton, X., Molemaker, M., and Gula, J.: Eddy-topography interactions and the fate of the Persian Gulf Outflow, J. Geophys. Res.-Oceans, 120, 6700-6717, doi:10.1002/2015JC011033, 2015.

Walsh, D.: A model of a mesoscale lens in large-scale shear - Part I: Linear calculations, J. Phys. Oceanogr., 25, 735-746, 1995.

Wang, Z., DiMarco, S. F., Stössel, M. M., Zhang, X., Howard, M. K., and du Vall, K.: Oscillation responses to tropical Cyclone Gonu in northern Arabian Sea from a moored observing system, Deep Sea Res. Pt. I, 64, 129-145, 2012.

Wang, Z., DiMarco, S. F., Jochens, A. E., and Ingle, S.: High salinity events in the northern Arabian Sea and Sea of Oman, Deep Sea Res. Pt. I, 74, 14-24, 2013. 